\title{
Effects of EGR rate on performance and emissions of a diesel power generator fueled by $B 7$
}

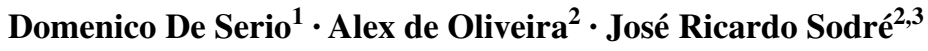

Received: 13 October 2016 / Accepted: 27 March 2017 / Published online: 3 April 2017

(C) The Author(s) 2017. This article is an open access publication

\begin{abstract}
This paper analyses the impacts of the application of an exhaust gas recirculation (EGR) system on the performance and emissions of a stationary, direct-injection diesel engine operating with diesel oil containing $7 \%$ biodiesel (B7). Experiments were carried out in a $49-\mathrm{kW}$ diesel power generator with the adapted EGR system, and engine performance and emissions were evaluated for different load and EGR settings. The results were compared with the engine operating with its original configuration without the EGR system, and revealed a reduction of peak cylinder pressure and fuel conversion efficiency, mainly at high engine loads. The use of EGR caused opposite effects on carbon dioxide $\left(\mathrm{CO}_{2}\right)$, carbon monoxide $(\mathrm{CO})$ and total hydrocarbons (THC) emissions, depending on load and EGR rate, showing an increase in most situations. The application of EGR consistently reduced oxides of nitrogen $\left(\mathrm{NO}_{\mathrm{X}}\right)$ emissions, reaching a maximum reduction close to $30 \%$. In general, the use of EGR increased $\mathrm{CO}_{2}, \mathrm{CO}$ and THC emissions
\end{abstract}

Technical Editor: Luis Fernando Figueira da Silva.

José Ricardo Sodré

ricardo@pucminas.br; ricardo.sodre@bcu.ac.uk

Domenico De Serio

deserio.dom@gmail.com

Alex de Oliveira

alexoem@gmail.com

1 Department of Energy (DENERG), Politecnico di Torino, C.so Duca degli Abruzzi, 24, 10129 Turin, Italy

2 Department of Mechanical Engineering, Pontifical Catholic University of Minas Gerais, Av. Dom José Gaspar, 500, Belo Horizonte, MG 30535-901, Brazil

3 School of Engineering and the Built Environment, Birmingham City University, Millenium Point, Curzon St, Birmingham B4 7XG, UK at high loads. The use of 7.5\% EGR was found to be at an adequate rate to simultaneously reduce $\mathrm{CO}, \mathrm{THC}$ and $\mathrm{NO}_{\mathrm{X}}$ emissions at low and moderate loads, without major penalties on $\mathrm{CO}_{2}$ emissions and engine performance.

Keywords Diesel engine - Exhaust gas recirculation · Emissions $\cdot$ Fuel conversion efficiency $\cdot$ Power generation

\section{Introduction}

The emissions produced by diesel engines have a serious impact on both the environment and human health. Significant amounts of oxides of nitrogen $\left(\mathrm{NO}_{\mathrm{X}}\right)$ are generated, which is a serious cause of smog, ground-level ozone, acid rain and also human diseases, such as asthma, coughing, or nausea [1]. Exhaust gas recirculation (EGR), which returns a portion of the engine exhaust gas to the combustion chamber via the intake system, shows a great potential to reduce $\mathrm{NO}_{\mathrm{X}}$ emissions [2,3]. The application of this technique to spark ignition and compression ignition engines has been studied with regard to its effects on engine performance, inlet air temperature control, combustion control and dual-fuel operation [4-12]. The possibility of reducing $\mathrm{NO}_{\mathrm{x}}$ emissions with the use of EGR rate results from thermal, chemical and dilution effects [8, 9, 13-16]. In the thermal effect, the high specific heat of exhaust carbon dioxide $\left(\mathrm{CO}_{2}\right)$ and water $\left(\mathrm{H}_{2} \mathrm{O}\right)$, compared to oxygen $\left(\mathrm{O}_{2}\right)$ and nitrogen $\left(\mathrm{N}_{2}\right)$ in the intake air, reduces combustion temperature. In the dilution effect, the reduction of oxygen mass fraction due to the displacement of some of the oxygen in the fresh intake air charge by inert gases causes a reduction in the local flame temperature because of the spatial broadening of the flame. In the chemical effect, recirculated $\mathrm{H}_{2} \mathrm{O}$ and $\mathrm{CO}_{2}$ are dissociated during combustion by 
an endothermic process, reducing flame temperature and modifying the $\mathrm{NO}_{\mathrm{X}}$ formation process.

Ladommatos et al. [17-20] presented a series of works focused on understanding the influence of EGR on combustion and emissions in a four-cylinder diesel engine. To simulate the different effects of EGR, the authors added synthetic gases in the engine intake manifold. Air dilution reduced in-cylinder peak pressure, heat release rate and temperature. Reduced availability of $\mathrm{O}_{2}$ decreased ignition delay, $\mathrm{NO}_{\mathrm{X}}$ and $\mathrm{NO}$, but increased unburned hydrocarbons (THC), soot, and particulate matter (PM) emissions. The studies highlight that $\mathrm{NO}_{\mathrm{X}}$ reduction is mostly due to the dilution effect, with a small contribution of the chemical effect, and a negligible contribution of the thermal effect.

Zheng et al. [21] also added synthetic gases to the engine intake air to reproduce the essential characteristics of EGR without the influence of temperature, pressure, gas concentration and transient effects of a real system. The results showed that increasing $\mathrm{CO}_{2}$ concentration reduces incylinder pressure and temperature during the compression stroke. The authors emphasize that EGR systems reduce $\mathrm{NO}_{\mathrm{X}}$ emissions, but may increase exhaust PM emissions, sulfur salts and other abrasive and corrosive substances that cause piston and cylinder wear.

The use of EGR is limited by increased PM emissions and reduced engine thermal efficiency, which causes a $\mathrm{NO}_{\mathrm{X}} / \mathrm{PM}$ trade-off $[9,14-16,22-24]$. He et al. [8] explain that the use of high EGR rates is possible with the delay of diesel injection, reducing engine efficiency losses, but with increasing soot emissions. The optimized EGR rate for THC, $\mathrm{CO}$ and $\mathrm{NO}_{\mathrm{X}}$ emissions is between 5 and $15 \%$. Hussain et al. [24] also observed that 15\% EGR rate is effective in reducing $\mathrm{NO}_{\mathrm{X}}$ emission substantially without deteriorating engine performance in terms of fuel conversion efficiency, brake specific fuel consumption, and emissions. The low oxygen level at high EGR rates causes incomplete soot oxidation [25] and leads to long-term problems, such as carbon deposits and lubricating oil degradation [26]. To overcome this conflict, low-temperature combustion techniques (LTC) may be employed [27]. These techniques aim to separate the event of diesel injection from combustion, to reduce $\mathrm{NO}_{\mathrm{X}}$ and soot emissions simultaneously. For the same EGR rate, the use of an oxygenated fuel, such as biodiesel, can simultaneously reduce THC, CO and smoke emissions, compared to diesel oil [1].

The use of EGR in transient state is a challenge due to fluctuations in the recirculation system, which can cause peaks of $\mathrm{NO}_{\mathrm{X}}$ and soot emissions [28]. Schubiger et al. [29] showed that the use of EGR in a diesel engine increased the premixed phase of combustion. Peak heat release rate was reduced at high loads and increased at low loads. Ignition delay and combustion duration were also increased. A EGR rate of $40 \%$ achieved extremely low levels of $\mathrm{NO}_{\mathrm{X}}$ emissions, but with increased emissions of PM, specific fuel consumption and engine noise levels.

Hussain et al. [24] and Agarwal et al. [30] noticed that diesel engines tolerate high EGR rates at low loads, since there is high oxygen concentration in these conditions, compared to high loads. With increasing load, inert gases are predominant in the exhaust, causing increased soot emissions due to reduced availability of oxygen. With EGR rates up to $20 \%$ a slight increase of fuel conversion efficiency at low loads was observed, explained by re-burning of hydrocarbons that enter the combustion chamber with the recirculated exhaust gas [30]. The authors reported reduced exhaust gas temperature, increased intake charge temperature and reduced fuel conversion efficiency with increasing EGR rate. EGR increased exhaust $\mathrm{CO}$ and THC emissions, and gas opacity, due to the dilution effect, and reduced $\mathrm{NO}_{\mathrm{X}}$ emissions, due to reduced flame temperature. A direct-injection diesel engine operating at constant speed with up to $30 \%$ of EGR rate achieved a reduction of up to $30 \%$ of $\mathrm{NO}_{\mathrm{X}}$ emissions, decreased exhaust gas temperature and increased ignition delay, opacity and $\mathrm{CO}$ emissions [31].

Selim et al. [32] and Niemi et al. [33] investigated the effects of using EGR cooling systems. The use of hot EGR increases in-cylinder pressure, which can decrease thermal efficiency losses due to a faster combustion, but cold EGR achieves lower $\mathrm{NO}_{\mathrm{X}}$ levels [32]. In comparison with hot EGR, the specific fuel consumption with cold EGR is higher for EGR rates up to $10 \%$, and lower with higher EGR rates [33]. Maiboom et al. [13] showed that, at constant EGR rate, the temperature of the recirculated exhaust gas causes different effects on engine performance. These effects depend on operating conditions, with positive and negative aspects using hot or cold EGR.

Wei et al. [34] stated that an engine with hot EGR can use the high exhaust gas temperature to heat the intake charge, thus improving combustion and fuel conversion efficiency, while the cooled EGR increases intake density and, thereby, engine volumetric efficiency. Whilst the decreased temperature of cold EGR can further reduce $\mathrm{NO}_{\mathrm{X}}$ emissions, THC emissions and cycle-by-cycle variations are increased compared with those of hot EGR. The difficulties of using EGR cooling systems are the deposits of THC, PM and soot inside the system, which produce fouling and cause degradation in the heat transfer performance [35, 36].

This work analyses the combustion characteristics, performance and emissions of a 49-kW stationary diesel engine operating with diesel fuel containing $7 \%$ biodiesel (B7), for different EGR rates and loads applied. The objective is to verify if the adaptation of an EGR system to an engine not originally conceived with this technology can satisfactorily reduce $\mathrm{NO}_{\mathrm{X}}$ without deteriorating engine performance or increasing other emissions $\left(\mathrm{CO}_{2}\right.$, $\mathrm{CO}$ and $\mathrm{THC}$ ). Furthermore, it aims to give an insight if 
the use of a fuel blend containing an oxygenated biofuel can counterbalance the reduced oxygen availability in the gas when using EGR. The choice of B7 is justified by the Brazilian government law No. 13033/2014, which established the compulsory addition of biodiesel to diesel oil to 7\% from 1 November 2014 [37]. With the use of the biofuel blend, it is expected that $\mathrm{CO}$ and THC can be adequately oxidized, thus avoiding significant increase of emissions of these components. Currently, there are no national regulations of gas emissions for diesel power generators in Brazil. To reduce the emissions in the city of São Paulo, the municipal government ruled that changes must be made to reduce the emissions of these equipments [38]. The use of EGR systems is an alternative to reduce $\mathrm{NO}_{\mathrm{X}}$ emissions from diesel power generators with simple mechanical modifications.

\section{Methodology}

\subsection{Experimental setup}

Experiments were carried out in a diesel power generator equipped with a naturally aspirated, four-stroke, four-cylinder diesel engine. Table 1 shows the main engine characteristics. The fuel was directly injected in the combustion chamber by a mechanically controlled system, and the fuel injection settings were not changed during the experiments.

For recirculation of the exhaust gas, an appropriate pipeline was installed with no insulation, therefore allowing the recirculated gas to partially cool down by natural convection external to the pipe. The EGR quantity was regulated by an electric valve installed in the EGR loop. An electronic system was developed to control the valve position and the EGR rate (\%). The EGR rate is defined as the mass percent of the recirculated exhaust gas $\left(M_{\mathrm{EGR}}\right)$ in the total intake mixture $\left(M_{\mathrm{in}}\right)$. Several authors report in their works $[13,14,21,24]$ that the EGR percentage can also be calculated as the recirculated $\mathrm{CO}_{2}$ fraction. The fresh intake air contains negligible amounts of $\mathrm{CO}_{2}$, while the recycled portion carries a substantial amount of $\mathrm{CO}_{2}$ produced from combustion that increases with EGR flow rate and engine load. Thus, comparing the $\mathrm{CO}_{2}$ concentrations in the engine exhaust $\left(\mathrm{CO}_{2}\right.$ exh $)$ and intake $\left(\mathrm{CO}_{2 \mathrm{EGR}}\right)$ is a practical way to determine EGR rate. Two taps were built in the intake and exhaust manifolds to sample the gas and measure $\mathrm{CO}_{2}$ concentration, for calculation of the EGR rates according to:

$\operatorname{EGR}(\%)=\frac{\left(\mathrm{CO}_{2 \_ \text {EGR }}-\mathrm{CO}_{2 \_ \text {atm }}\right)}{\left(\mathrm{CO}_{2 \_ \text {exh }}-\mathrm{CO}_{2 \_ \text {atm }}\right)}$.
Table 1 Diesel engine specifications

\begin{tabular}{ll}
\hline Parameter & Type or value \\
\hline Model & MWM D229-4 \\
No. of cylinders & 4 \\
No. of strokes & 4 \\
Type of injection & Direct \\
Bore $\times$ stroke & $102 \mathrm{~mm} \times 120 \mathrm{~mm}$ \\
Total displacement & $3.922 \mathrm{~L}$ \\
Firing order & $1-3-4-2$ \\
Maximum power at $1800 \mathrm{rpm}$ & $44 \mathrm{~kW}$ \\
Aspiration & Natural \\
Compression ratio & $17: 1$ \\
Coolant & Water \\
\hline
\end{tabular}

A data acquisition system was used to assess engine performance. The system consists of sensors, transducers, signal conditioning circuits, two data acquisition boards and a program developed in LabVIEW platform. A schematic drawing of the experimental apparatus is shown by Fig. 1. The intake air mass flow rate was measured by an orifice plate with uncertainty of $\pm 2.3 \mathrm{~kg} / \mathrm{h}$. Fuel consumption was measured by a platform balance with uncertainty of $\pm 0.1 \mathrm{~kg} / \mathrm{h}$. K-type thermocouples were used to measure temperature in several locations, including fuel tank, ambient air, inlet air, orifice plate inlet, and exhaust gas, with uncertainty of $\pm 2{ }^{\circ} \mathrm{C}$. Cooling water temperature was measured by a PT-100 sensor, also with uncertainty of $\pm 2{ }^{\circ} \mathrm{C}$. The inlet air humidity was determined by a thermohygrometer with uncertainty of $\pm 2.5 \%$ of reading, and ambient pressure was monitored by a Torricelli barometer with resolution of $\pm 1.3 \mathrm{kPa}$.

The engine load was measured by an electric transducer with uncertainty of $\pm 1 \%$. The in-cylinder pressure was measured by a piezoelectric pressure transducer with resolution of $\pm 0.5 \%$. Total HC emissions were analysed by a heated flame ionization detector (HFID) with resolution of $\pm 1 \mathrm{ppm} . \mathrm{NO}_{\mathrm{X}}$ emissions were analysed by a heated chemiluminescent analyser (HCLD) with resolution of $\pm 1 \mathrm{ppm}$. $\mathrm{CO}$ and $\mathrm{CO}_{2}$ emissions were measured by non-dispersive infrared (NDIR) analysers with resolution of $\pm 1 \mathrm{ppm}$ and $\pm 0.01 \%$, respectively.

\subsection{Experimental procedure}

The fuel used was a commercial N. 2 diesel oil containing $7 \%$ of biodiesel, whose values of density, viscosity and water content are shown in Table 2. The engine load was varied from 0 to $30 \mathrm{~kW}$ in intervals of $5 \mathrm{~kW}$ at the constant engine speed of $1800 \mathrm{rev} / \mathrm{min}$. This speed was chosen because it provides an output power frequency of $60 \mathrm{~Hz}$, which is the standard value of Brazilian electric power 
Fig. 1 Schematics of the experimental apparatus

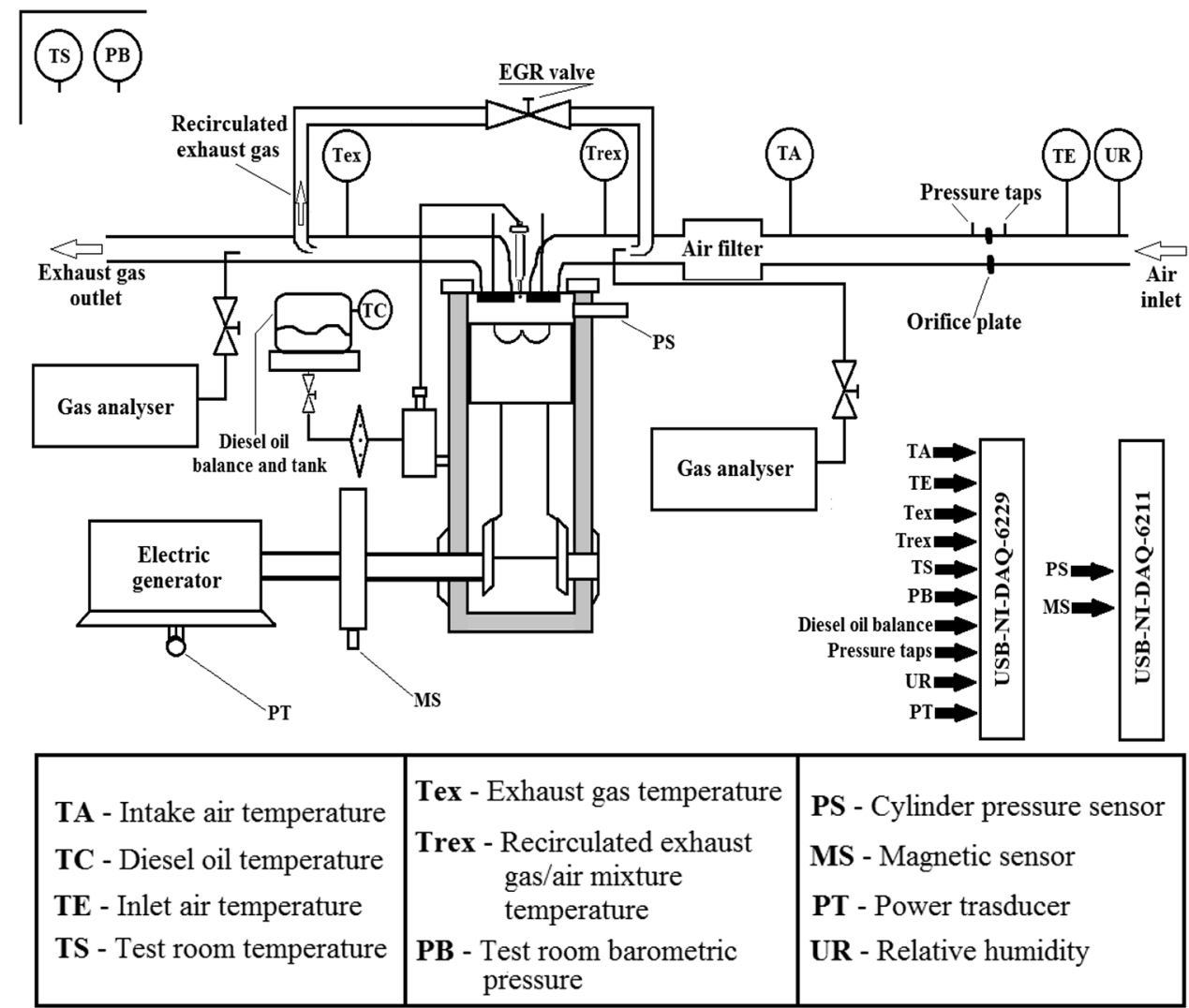

Table 2 Properties of diesel oil-ethanol blends

\begin{tabular}{lcl}
\hline Property & Value & Method \\
\hline Density at $20{ }^{\circ} \mathrm{C}\left(\mathrm{kg} / \mathrm{m}^{3}\right)$ & $842 \pm 1$ & ASTM D4052 \\
Viscosity at $40{ }^{\circ} \mathrm{C}\left(\mathrm{mm}^{3} / \mathrm{s}\right)$ & $3.0 \pm 0.1$ & ASTM D7042 \\
Water content $(\mathrm{mg} / \mathrm{kg})$ & $103 \pm 2$ & ASTM E203 \\
\hline
\end{tabular}

grid. The ISO 3046-1:2002 standard was used to correct the load power and fuel consumption to standard conditions. The engine was operated with and without EGR, and the results compared. The EGR rates used were 0\% (EGR0), $2.5 \%$ (EGR2.5), 5.0\% (EGR5), 7.5\% (EGR7.5) and $10.0 \%$ (EGR10).

The experiments were performed under steady-state conditions, after the exhaust gas temperature and the cooling water temperature were stabilized. In each test, a fixed load was applied during $10 \mathrm{~min}$, which included the stabilization period followed by data measurement and acquisition at steady state. Depending on the load applied, the stabilization period was 2-5 min; therefore, the period of data acquisition in a single test at fixed load corresponded to a minimum of 4500 engine cycles. The results shown in the following section represent the average of three tests at each load, varying the engine load from 0 to $30 \mathrm{~kW}$. The
Table 3 Total uncertainty of the measured parameters

\begin{tabular}{ll}
\hline Parameter & Uncertainty \\
\hline Load power & $0.02 \mathrm{~kW}$ \\
Specific fuel consumption & $0.02 \mathrm{~g} / \mathrm{kW} \mathrm{h}$ \\
$\mathrm{CO}_{2}$ emissions & $6.00 \mathrm{~g} / \mathrm{kW} \mathrm{h}$ \\
$\mathrm{CO}$ emissions & $0.21 \mathrm{~g} / \mathrm{kW} \mathrm{h}$ \\
$\mathrm{THC}$ emissions & $0.18 \mathrm{~g} / \mathrm{kW} \mathrm{h}$ \\
$\mathrm{NO}_{\mathrm{X}}$ emissions & $0.05 \mathrm{~g} / \mathrm{kW} \mathrm{h}$ \\
\hline
\end{tabular}

uncertainties of the measurements were calculated following the methodology by Kline and McClintock [39].

\section{Results and discussion}

The engine was operated at $1800 \mathrm{rpm}$ with different loads and EGR rates (from 0 to $10 \%$ ) to investigate the effect of EGR on engine performance and emissions. The performance and emission data were analysed and presented graphically for gas pressure inside the cylinder, heat release rate, air mass flow rate, thermal efficiency, $\mathrm{CO}_{2}, \mathrm{CO}, \mathrm{THC}$ and $\mathrm{NO}_{\mathrm{X}}$-specific emissions. The uncertainties of the measurements are presented in Table 3. 
The in-cylinder pressure and the corresponding heat release rate at the load of $25 \mathrm{~kW}$ are shown in Figs. 2 and 3, respectively. The peak pressures are slightly decreased for all the EGR rates, by about $2 \%$, in comparison with operation with no EGR (Fig. 2), in accordance with Refs. [4, 6, $21,22,25]$. The use of EGR increases the intake charge specific heat capacity and reduces $\mathrm{O}_{2}$ availability, which has a negative effect on the combustion rate and leads to reduced values of peak cylinder. Moreover, the dissociation of $\mathrm{H}_{2} \mathrm{O}$ and $\mathrm{CO}_{2}$ reduces the flame temperature, due to an endothermic process, leading to a reduction in $\mathrm{NO}_{\mathrm{X}}$ formation. As a consequence of decreased combustion temperature, the peak heat release rate is also reduced with the use of EGR (Fig. 3). The higher reductions of the peak heat release rate were observed for operation with 7.5 and $10 \%$ EGR. The biodiesel effects have not been investigated here, but, according to the literature, its presence in the diesel fuel may have caused a slight reduction in the in-cylinder peak pressure and peak heat release, especially at full load, mainly due to poor atomization and inadequate air-fuel mixing of biodiesel blends [40, 41].

Figure 4 shows the intake air mass flow rate for operation with different EGR rates. Since part of the intake air is replaced by the exhaust gas, increasing EGR rate reduces the intake air mass flow rate. Compared with no use of EGR (EGR0), the average reductions found were of $3 \%$ for EGR2.5, 4\% for EGR5, 7\% for EGR7.5, and 9\% for EGR10. The engine volumetric efficiency is also affected at the same proportions, as less air amount is admitted into the engine cylinders with increasing EGR rates. At a given EGR, the small variations of the intake air mass flow rate with engine load power are within the uncertainty of the measurements, as indicated by the error bars.

These variations are due to changes of the intake air temperature. With increasing load power the heat release rate is increased [42], and thus the ambient and intake air temperatures are also increased, reducing the intake air mass flow rate. To keep the intake air mass flow rate approximately constant, an order of decreasing load application was adopted during the tests. Similar to the intake air mass flow, the intake air volumetric flow slightly changed at a given EGR rate due to small variations in the intake air temperature and pressure with load variation. As in the case of the intake air mass flow, the changes in the volumetric flow at a fixed EGR were within the uncertainty of the measurements.

Figure 5 presents the variation in fuel conversion efficiency, normalized to the standard atmospheric conditions, for different loads and EGR rates. The use of EGR causes a negative effect on fuel conversion efficiency, being in agreement with the behaviour reported by Refs. [10, $24,30-32]$. The decrease of fuel conversion efficiency is mainly due to the reduction of air/fuel ratio (Fig. 6) [4].

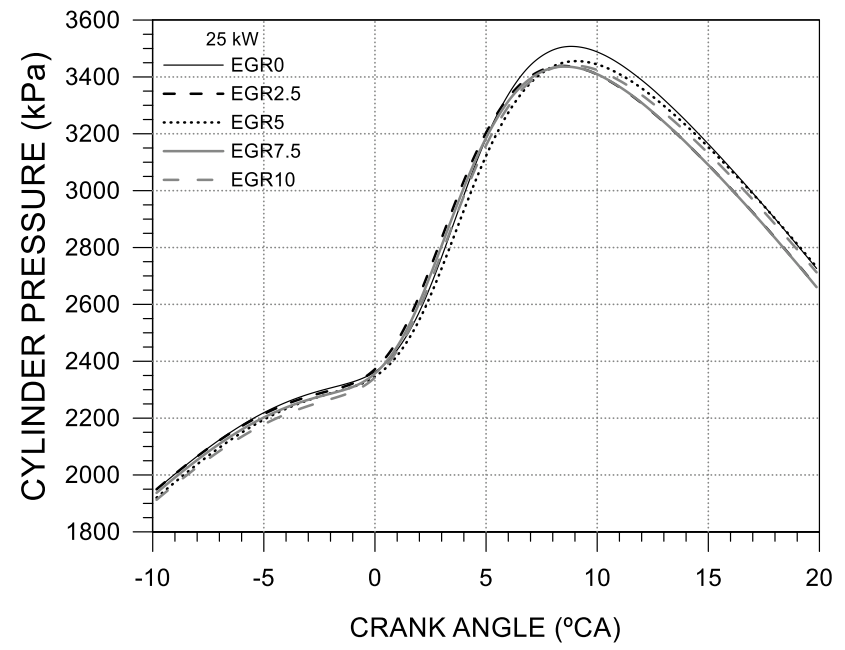

Fig. 2 In-cylinder pressure diagram at $25 \mathrm{~kW}$ for different EGR rates

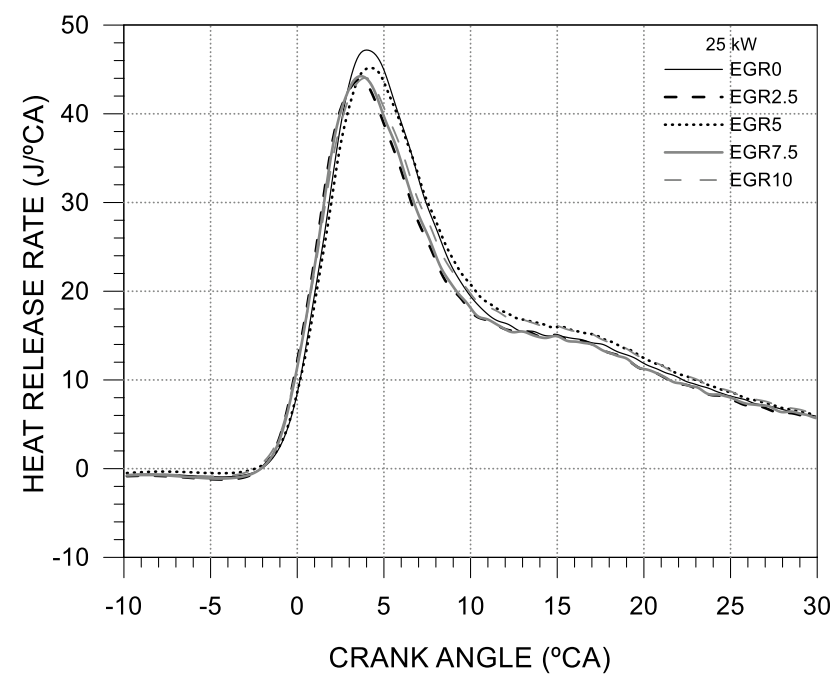

Fig. 3 Heat release rate curve at $25 \mathrm{~kW}$ for different EGR rates

Fuel conversion efficiency is not significantly affected by EGR only in the extremes of the load range investigated, at 5 and $30 \mathrm{~kW}$, where the values are close to EGR0. For all intermediate loads fuel conversion efficiency decreases with the use of EGR. The maximum decrease was 5.7\%, for operation with $10 \%$ EGR and $25 \mathrm{~kW}$ load. Thus, in general, it is not attractive to use high EGR rates at high loads because combustion tends to deteriorate, leading to reduced fuel conversion efficiency.

The effects of EGR on $\mathrm{CO}_{2}, \mathrm{CO}$ and THC emissions are shown in Figs. 7, 8 and 9. In general, it is noticed that $\mathrm{CO}_{2}$, $\mathrm{CO}$ and THC emissions increase with the use of EGR. The trend presented by $\mathrm{CO}_{2}$ (Fig. 7) is explained by the fact that the fresh intake air contains negligible amounts of $\mathrm{CO}_{2}$, while the EGR fraction carries a substantial amount of 


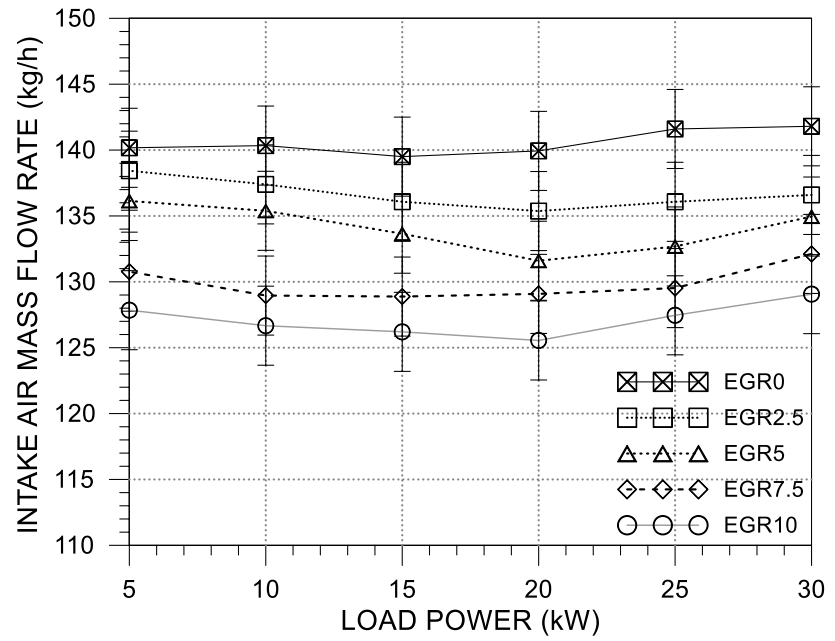

Fig. 4 Variation of intake air mass flow rate with EGR rate and load

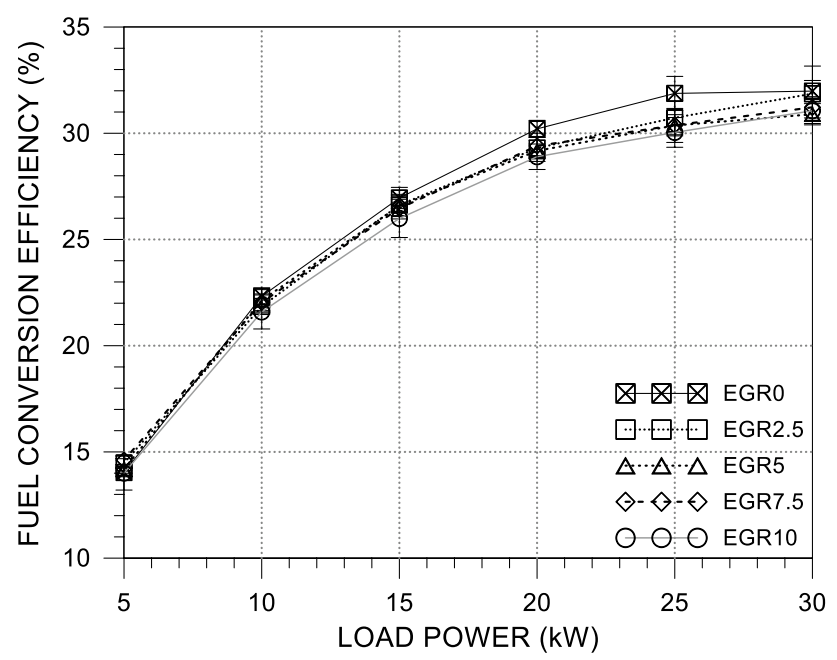

Fig. 5 Variation of fuel conversion efficiency with EGR rate and load

$\mathrm{CO}_{2}$, which is higher with increasing EGR flow rate and engine load [15, 21]. The highest increases of $\mathrm{CO}_{2}$ emissions were 11.6 and $11.2 \%$, for $7.5 \%$ EGR and $10 \%$ EGR, respectively, at the load of $30 \mathrm{~kW}$. At $10 \mathrm{~kW}$ and lower engine loads, the EGR rate did not significantly affect $\mathrm{CO}_{2}$ emissions.

Carbon monoxide emissions result from incomplete combustion and are largely dependent on air-fuel ratio [6]. The increase of EGR rate reduces oxygen availability in the combustion chamber and decelerates the reaction rates of the air-fuel mixture, thus producing lower temperatures [3, 30]. In such a case, the flame propagation may not be sustained with relatively lean mixtures. Thus, the heterogeneous mixture does not burn completely, resulting in higher $\mathrm{CO}$ and THC emissions as observed in most situations

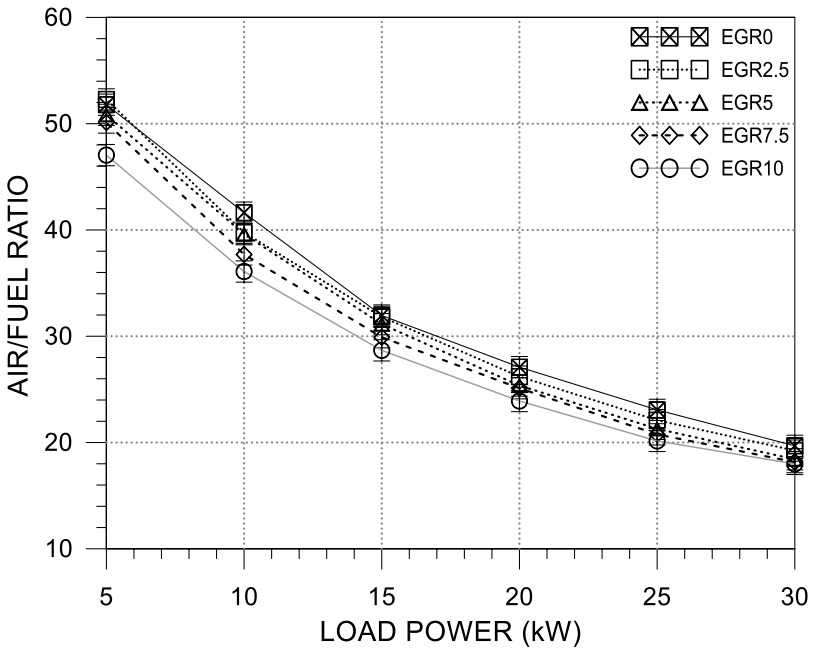

Fig. 6 Variation of mixture air/fuel ratio with EGR rate and load

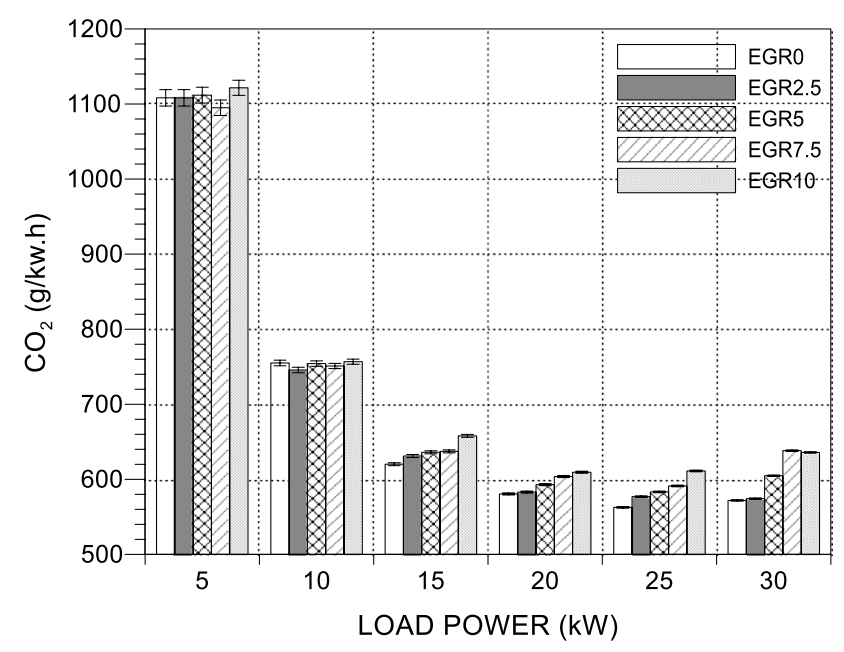

Fig. 7 Variation of carbon dioxide emissions with EGR rate and load

(Figs. 8, 9), being in agreement with Refs. [10, 24, 30, 34]. The largest CO increment was observed for $10 \%$ EGR and $30 \mathrm{~kW}$ engine load, of $41.7 \%$ (Fig. 8).

With regard to THC-specific emissions, the largest increases in comparison with EGR0 were found for minimum EGR (EGR2.5) at any load, or maximum load $(30 \mathrm{~kW})$ at any EGR rate. The maximum increase recorded was $27.4 \%$, for $2.5 \%$ EGR and $30 \mathrm{~kW}$. Decreased THC emissions were observed with the use of 5\% EGR and $10 \mathrm{~kW}$ load or lower, and 7.5\% EGR with $25 \mathrm{~kW}$ load or lower. At high load, the increase of THC is explained by the higher fuel amount injected to meet the demand, also originating higher amounts of unburned fuel. With $2.5 \%$ EGR, the intake air charge and fuel injection amount were not substantially modified in comparison with EGR0 (Figs. 4, 5), but the small presence of the exhaust gas recirculated 
Fig. 8 Variation of carbon monoxide emissions with EGR rate and load

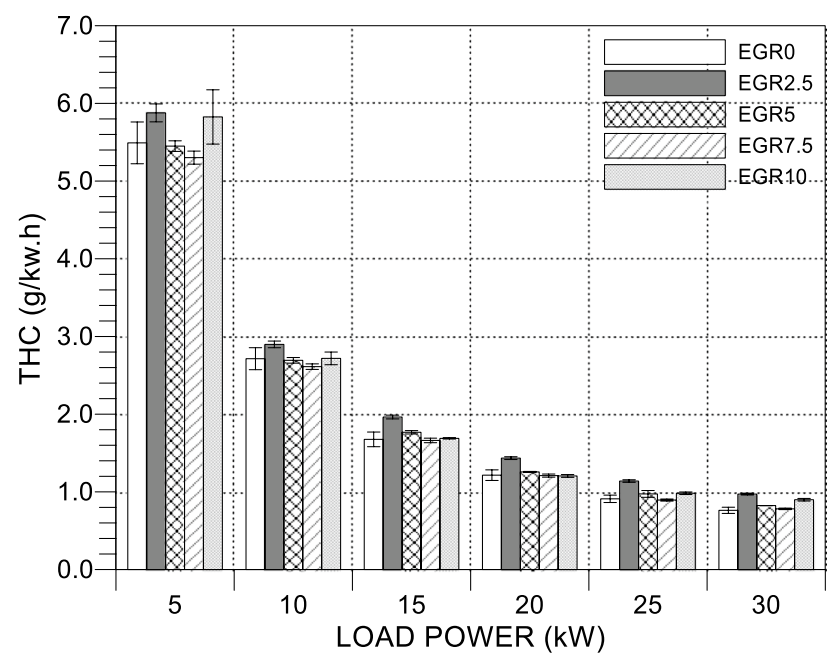

Fig. 9 Variation of total hydrocarbon emissions with EGR rate and load

was enough to intensify incomplete combustion and generate unburned hydrocarbons. With higher EGR rates, there was a substantial reduction of the intake air to the cylinder (Fig. 4) and, therefore, oxygen availability in the gas. However, with high EGR rates, mixture enrichment (Fig. 5) using a fuel blend with an oxygenated fuel counterbalanced the awkward effects of low oxygen availability in the gas, not allowing hydrocarbon formation to increase.

Figure 10 shows that $\mathrm{NO}_{\mathrm{X}}$-specific emissions are reduced with increasing EGR rate for all engine load range investigated. This behaviour is justified by the reduction of oxygen availability due to the displacement of some of the oxygen in the fresh intake air charge by the recirculated

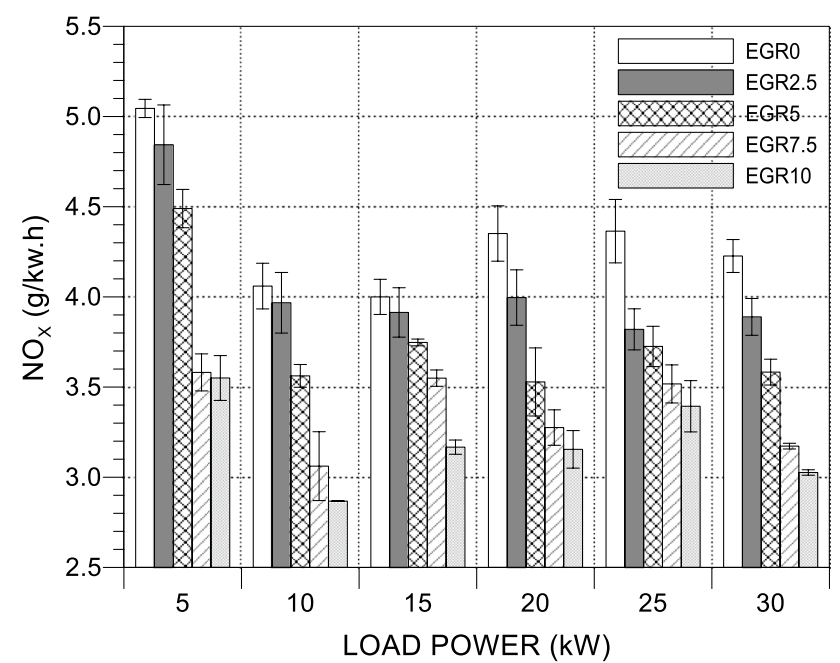

Fig. 10 Variation of oxides of nitrogen emissions with EGR rate and load

exhaust gas [30, 43-48]. This causes a reduction in the local flame temperature because of the spatial broadening of the flame due to the reduction in the oxygen molar fraction [24]. Also, there is the thermal effect due to the increase in the average specific heat capacity of the gases in the combustion zone, since the recirculated exhaust gas contains $\mathrm{CO}_{2}$ and $\mathrm{H}_{2} \mathrm{O}$ with higher specific heat than that of air. Finally, there is a reduction in the combustion temperature due to endothermic chemical reactions, such as $\mathrm{CO}_{2}$ and $\mathrm{H}_{2} \mathrm{O}$ dissociation $[4,13]$. Using $10 \%$ EGR, the reductions on $\mathrm{NO}_{\mathrm{X}}$ emissions ranged from 20.8 to $29.6 \%$ for the different loads. Using $2.5 \%$ EGR, the decrease on $\mathrm{NO}_{\mathrm{X}}$ remissions ranged from 2.2 to $12.5 \%$. 


\section{Conclusions}

The use of EGR was shown to be feasible for reduction of $\mathrm{NO}_{\mathrm{X}}$ emissions from a diesel power generator with the adapted technology operating with B7. A reduction of nearly $30 \%$ of $\mathrm{NO}_{\mathrm{X}}$ emissions was reached using $10 \%$ EGR rate. With $2.5 \%$ EGR, the maximum reduction of $\mathrm{NO}_{\mathrm{X}}$ emissions was $12.5 \%$. With increasing EGR rate, the in-cylinder peak pressure and the peak heat release rate decreased. In most situations, the use of EGR increased $\mathrm{CO}_{2}, \mathrm{CO}$ and THC emissions, especially at high loads. However, under certain load conditions and EGR rates, decreased levels of those components were observed with the use of EGR. Based on these results, for simultaneous decrease of $\mathrm{NO}_{\mathrm{X}}, \mathrm{CO}$ and THC emissions, with only small increases on $\mathrm{CO}_{2}$ emissions, if any, it is recommended the use of $7.5 \%$ EGR at low and moderate loads.

Acknowledgements The authors thank CAPES, CNPq research project 304114/2013-8, and FAPEMIG research projects TEC PPM 0385-15 and TEC APQ 0014-11 for the financial support to this work.

Open Access This article is distributed under the terms of the Creative Commons Attribution 4.0 International License (http://creativecommons.org/licenses/by/4.0/), which permits unrestricted use, distribution, and reproduction in any medium, provided you give appropriate credit to the original author(s) and the source, provide a link to the Creative Commons license, and indicate if changes were made.

\section{References}

1. Turns SR (2013) Introduction to combustion. Mc Graw-Hill, New York

2. Palash SM, Masjuki HH, Kalam MA, Masum BM, Sanjid A, Abedin MJ (2013) State of the art of NOx mitigation technologies and their effect on the performance and emission characteristics of biodiesel-fueled Compression Ignition engines. Energ Convers Manag 76:400-420. doi:10.1016/j. enconman.2013.07.059

3. Bermúdez V, Lujan JM, Pla B, Linares WG (2011) Effects of low pressure exhaust gas recirculation on regulated and unregulated gaseous emissions during NEDC in a light-duty diesel engine. Energy 36:5655-5665. doi:10.1016/j.energy.2011.06.061

4. Hountalas DT, Mavropoulos GC, Binder KB (2008) Effect of exhaust gas recirculation (EGR) temperature for various EGR rates on heavy duty DI diesel engine performance and emissions. Energy 33:272-283. doi:10.1016/j.energy.2007.07.002

5. Park SH, Junepyo C, Lee CS (2010) Effects of bioethanolblended diesel fuel on combustion and emission reduction characteristics in a direct-injection diesel engine with exhaust gas recirculation (EGR). Energ Fuel 24:3872-3883. doi:10.1021/ ef100233b

6. Park SH, Youn IM, Lee CS (2010) Influence of two-stage injection and exhaust gas recirculation on the emissions reduction in an ethanol-blended diesel-fueled four-cylinder diesel engine. Fuel Process Technol 91:1753-1760. doi:10.1016/j. fuproc.2010.07.016
7. Ishida M, Yamamoto S, Ueki H, Sakaguchi D (2010) Remarkable improvement of $\mathrm{NO}_{\mathrm{X}}-\mathrm{PM}$ trade-off in a diesel engine by means of bioethanol and EGR. Energy 35:4572-4581. doi:10.1016/j. energy.2010.03.039

8. He BQ (2016) Advances in emission characteristics of diesel engines using different biodiesel fuels. Renew Sust Energ Rev 60:570-586. doi:10.1016/j.rser.2016.01.093

9. Divekar PD, Chen X, Tjong J, Zheng M (2016) Energy efficiency impact of EGR on organizing clean combustion in diesel engines. Energ Convers Manage 112:369-381. doi:10.1016/j. enconman.2016.01.042

10. Kumar BR, Saravanan S, Rana D, Anish V, Nagendran A (2016) Effect of a sustainable biofuel-n-octanol-on the combustion, performance and emissions of a DI diesel engine under naturally aspirated and exhaust recirculation (EGR) modes. Energ Convers Manag 118:275-286. doi:10.1016/j.enconman.2016.04.001

11. Bozza F, De Bellis V, Teodosio L (2016) Potentials of cooled EGR and water injection for knock resistance and fuel consumption improvements of gasoline engines. Appl Energ 169:112125. doi:10.1016/j.apenergy.2016.01.129

12. Mohammadi A, Ishiyama T, Kakuta T, Kee SS (2005) Fuel injection strategy for clean diesel engine using ethanol blended diesel fuel. SAE Technical Papers Series 2005-01-1725

13. Maiboom A, Tauzia X, Hétet JF (2008) Experimental study of various effects of exhaust gas recirculation (EGR) on combustion and emissions of an automotive direct injection diesel engine. Energy 33:22-34. doi:10.1016/j.energy.2007.08.010

14. Millo F, Giacominetto PF, Bernardi MG (2012) Analysis of different exhaust gas recirculation architectures for passenger car Diesel engines. Appl Energ 98:79-91. doi:10.1016/j. apenergy.2012.02.081

15. Hebbar GS, Bhat AK (2013) Control of $\mathrm{NO}_{\mathrm{X}}$ from a DI diesel engine with hot EGR and ethanol fumigation: an experimental investigation. Int J Automot Techn 14:333-341. doi:10.1007/ s12239-013-0037-8

16. Asad U, Zheng M (2014) Exhaust gas recirculation for advanced diesel combustion cycles. Appl Energy 123:242-252. doi:10.1016/j.apenergy.2014.02.073

17. Ladommatos N, Abdelhalim SM, Zhao H, Hu Z (1996) The dilution, chemical, and thermal effects of exhaust gas recirculation on diesel engine emissions-part 1: effect of reducing inlet charge oxygen. SAE Technical Papers Series 961165

18. Ladommatos N, Abdelhalim SM, Zhao H, Hu Z (1996) The dilution, chemical, and thermal effects of exhaust gas recirculation on diesel engine emissions-part 2: effects of carbon dioxide. SAE Technical Papers Series 961167

19. Ladommatos N, Abdelhalim SM, Zhao H, Hu Z (1996) The Dilution, chemical, and thermal effects of exhaust gas recirculation on diesel engine emissions-part 3: effects of water vapour. SAE Technical Papers Series 971659

20. Ladommatos N, Abdelhalim SM, Zhao H, Hu Z (1997) The dilution, chemical, and thermal effects of exhaust gas recirculation on diesel engine emissions-part 4: effects of carbon dioxide and water vapour. SAE Technical Papers Series 971660

21. Zheng M, Reader GT, Hawley JG (2004) Diesel engine exhaust gas recirculation-a review on advanced and novel concepts. Energ Convers Manag 45:883-900. doi:10.1016/ S0196-8904(03)00194-8

22. Abd-Alla GH (2002) Using exhaust gas recirculation in internal combustion engine: a review. Energ Convers Manag 43:10271042. doi:10.1016/S0196-8904(01)00091-7

23. Alriksson M, Rente T, Denbratt I (2005) Low soot, low NOx in a heavy duty diesel engine using high levels of EGR. SAE Technical Paper Series 2005-01-3836

24. Hussain J, Palaniradja K, Alagumurthi N, Manimaran R (2012) Effect of exhaust gas recirculation (EGR) on performance and 
emission characteristics of a three cylinder direct injection compression ignition engine. AEJ 51:241-247. doi:10.1016/j. aej.2012.09.004

25. Li X, Xu Z, Guan C, Huang Z (2014) Impact of exhaust gas recirculation (EGR) on soot reactivity from a diesel engine operating at high load. Appl Therm Eng 68:100-106. doi:10.1016/j. applthermaleng.2014.04.029

26. Solaimuthu C, Ganesan V, Senthilkumar D, Ramasamy KK (2015) Emission reductions studies of a biodiesel engine using EGR and SCR for agriculture operations in developing countries. Appl Energ 138:91-98. doi:10.1016/j.apenergy.2014.04.023

27. Asad U, Kumar R, Zheng M, Tjong J (2015) Ethanol-fueled low temperature combustion: a pathway to clean and efficient diesel engine cycles. Appl Energ 157:838-850. doi:10.1016/j. apenergy.2015.01.057

28. Asad U, Tjong J, Zheng M (2014) Exhaust gas recirculationZero-dimensional modelling and characterization for transient diesel combustion control. Energ Convers Manage 86:309-324. doi:10.1016/j.enconman.2014.05.035

29. Schubiger R, Bertola A, Boulouchos K (2001) Influence of EGR on combustion and exhaust emissions of heavy duty DI-diesel engines equipped with common-rail injection systems. SAE Technical Papers Series 2001-01-3497

30. Agarwal D, Singh SK, Agarwal AK (2011) Effect of exhaust gas recirculation (EGR) on performance, emissions, deposits and durability of constant speed compression ignition engine. Appl Energ 8:2900-2907. doi:10.1016/j.apenergy.2011.01.066

31. Kumar BR, Saravanan S (2015) Effect of exhaust gas recirculation (EGR) on performance and emissions of a constant speed DI diesel engine fueled with pentanol/diesel blends. Fuel 160:217226. doi:10.1016/j.fuel.2015.07.089

32. Selim MYE (2003) A study of some combustion characteristics of dual fuel engine using EGR. SAE Technical Papers Series 2003-01-0766

33. Niemi SA, Paanu TPJ, Laurén MJ (2004) Effect of injection timing, EGR and EGR cooling on the exhaust particle number and size distribution of an off-road diesel engine. SAE Technical Paper Series 2004-01-1988

34. Wei H, Zhu T, Shu G, Tan L, Wang Y (2012) Gasoline engine exhaust gas recirculation-a review. Appl Energy 99:534-544. doi:10.1016/j.apenergy.2012.05.011

35. Hong SK, Lee KS, Song S, Chun KM, Chung D, Min S (2011) Parametric study on particle size and SOF effects on EGR cooler fouling. Atmos Environ 45:5677-5683. doi:10.1016/j. atmosenv.2011.07.036
36. Lee J, Min K (2014) A study of the fouling characteristics of EGR coolers in diesel engines. J Mech Sci Technol 28:33953401. doi:10.1007/s12206-014-0752-8

37. Planalto.gov.br. (2014) Lei Nr. 13033-Adição obrigatória de biodiesel ao óleo diesel. http://www.planalto.gov.br/ccivil_03/_ Ato2011-2014/2014/Lei/L13033.htm. Accessed 30 Feb 2017

38. Salvador R, Bringhenti C, Tomita JT (2016) Characterization of an ethanol fueled heavy duty engine powering a generator set. Appl Therm Eng 102:1395-1402. doi:10.1016/j. applthermaleng.2016.03.107

39. Kline SJ, McClintock FA (1953) Describing uncertainties in single sample experiments. Mechanical Engineering 75:3-8

40. Öztürk E (2015) Performance, emission, combustion and injection characteristics of a diesel engine fueled with canola oilhazelnut soapstock biodiesel mixture. Fuel Process Technol 129:183-191. doi:10.1016/j.fuproc.2014.09.016

41. Buyukkaya E (2010) Effects of biodiesel on a DI diesel engine performance, emission and combustion characteristics. Fuel 89:3099-3105. doi:10.1016/j.fuel.2010.05.034

42. Oliveira A, Morais AM, Valente OS, Sodre JR (2016) Combustion, performance and emissions of a diesel power generator with direct injection of B7 and port injection of ethanol. Brazil J Mech Sci Eng. doi:10.1007/s40430-016-0667-7

43. Choi S, Park W, Lee S, Min K, Choi H (2011) Methods for incylinder EGR stratification and its effects on combustion and emission characteristics in a diesel engine. Energy 36:69486959. doi:10.1016/j.energy.2011.09.016

44. Guo M, Fu Z, Ma D, Ji N, Song C, Liu Q (2015) A short review of treatment methods of marine diesel engine exhaust gases. Procedia Eng 121:938-943. doi:10.1016/j.proeng.2015.09.059

45. Stein HJ (1996) Diesel oxidation catalysts for commercial vehicle engines: strategies on their application for controlling particulate emissions. Appl Catal B-Environ 10(1-3):69-82. doi:10.1016/0926-3373(96)00024-0

46. Resitoglu IA, Altinisik K (2015) The pollutant emissions from diesel-engine vehicles and exhaust aftertreatment systems. Clean Technol Envir 17:15-27. doi:10.1007/s10098-014-0793-9

47. Zervas E (2008) Impact of different configurations of a diesel oxidation catalyst on the $\mathrm{CO}$ and $\mathrm{HC}$ tail-pipe emissions of a Euro4 passenger car. Appl Therm Eng 28:962-966. doi:10.1016/j.applthermaleng.2007.06.033

48. Park Y, Bae C (2014) Experimental study on the effects of high/ low pressure EGR proportion in a passenger car diesel engine. Appl Energy 133:308-316. doi:10.1016/j.apenergy.2014.08.003 